\title{
Saprobic Dothideomycetes in Thailand: Muritestudina gen. et sp. nov. (Testudinaceae) a new terrestrial pleosporalean ascomycete, with hyaline and muriform ascospores
}

\author{
Wanasinghe $\mathrm{DN}^{1,2}$, Jeewon $\mathrm{R}^{3}$, Tibpromma $\mathrm{S}^{1,2}$, Jones $\mathrm{EBG}^{4}$ and Hyde $\mathrm{KD}^{1,2^{*}}$ \\ ${ }^{1}$ Center of Excellence in Fungal Research, Mae Fah Luang University, Chiang Rai, 57100, Thailand \\ ${ }^{2}$ Key Laboratory for Plant Diversity and Biogeography of East Asia, Kunming Institute of Botany, Chinese Academy of \\ Science, Kunming 650201, Yunnan, People's Republic of China \\ ${ }^{3}$ Department of Health Sciences, Faculty of Science, University of Mauritius, Reduit, Mauritius \\ ${ }^{4}$ Nantgaredig, 33 B St. Edwards Road, Southsea, Hants, Hampshire PO5 3DH, UK
}

Wanasinghe DN, Jeewon R, Tibpromma S, Jones EBG, Hyde KD 2017 - Saprobic Dothideomycetes in Thailand: Muritestudina gen. et sp. nov. (Testudinaceae) a new terrestrial pleosporalean ascomycete, with hyaline and muriform ascospores. Studies in Fungi 2(1), 219-234, Doi $10.5943 / \mathrm{sif} / 2 / 1 / 26$

\begin{abstract}
The family Testudinaceae and its intergeneric classification are poorly understood. This is due to overlap of morphological characteristics in genera and lack of DNA sequence data to infer phylogenetic relationships. The main objective of the present paper is to establish a novel genus, Muritestudina, based on distinct morphological characteristics and analyses of combined LSU, SSU, ITS, rpb2 and tef1 sequence data. We also fill the gap of our current knowledge on the phylogenetic position of Testudinaceae. Based on the morphological characteristics of species representing existing genera of Testudinaceae, we herein introduce a new genus, Muritestudina with $M$. chiangraiensis as the type species. The new genus is characterized by globose to subglobose, ostiolate ascomata; a peridium of brown to dark-brown cells of textura angularis; septate and cellular pseudoparaphyses; cylindric-clavate asci with a distinct pedicel; and hyaline, ellipsoidal and muriform ascospores. The new genus differs from the other genera in Testudinaceae in having hyaline, muriform ascospores. Combined analyses of ribosomal and protein coding gene sequence data confirmed that our new taxon belongs in Testudinaceae with a close relationship with Neotestudina rosatii.
\end{abstract}

Keywords - Ascomycota - phylogeny - Pleosporales - taxonomy

\section{Introduction}

The biology that deals with the classification and nomenclature of Dothideomycetes has undergone considerable change and to-date this largely cosmopolitan class contains 32 orders and 114 families (Liu et al. 2017). Most taxa of Dothideomycetes are plant associated fungi and may be pathogens, endophytes, saprobes, or epiphytes of a wide range of hosts, in terrestrial as well as aquatic habitats (Duong et al. 2006, Kodsueb et al. 2007, Zhang et al. 2008, Hyde et al. 2013, 2014, Wijayawardene et al. 2014, Li et al 2017, Luo et al. 2017). They contribute both positively and negatively to human and economic well-being, by affecting environmental cost and being a risk to agriculture. They also have pharmaceutical and biotechnological significance (Ohm et al. 2012, Stergiopoulos et al. 2012, Torres \& Dela Cruz 2015). 
Pleosporales is the largest order, comprising a quarter of all dothideomycetous species (Kirk et al. 2008). Pleosporales comprises 55 families and has an estimated divergence time (crown age) of 148-260 MY (Liu et al. 2017). Due to their economic importance and diversity, there has been a great research interest on taxa of this order, which has provided a better taxonomic understanding (Jaklitsch \& Voglmayr 2016, Chen et al. 2017, Hashimoto et al. 2017, Wanasinghe et al. 2017a, b, Woudenberg et al. 2017). However, in contrast to the well-resolved families of Pleosporales (i.e. Camarosporidiellaceae, Didymellaceae, Didymosphaeriaceae, Leptosphaeriaceae, Lophiostomataceae, Lophiotremataceae, Melanommataceae, Nigrogranaceae, Phaeosphaeriaceae, Pleosporaceae), many of genera and families are poorly understood (i.e. Delitschiaceae, Halojulellaceae, Ligninsphaeriaceae, Morosphaeriaceae, Salsugineaceae, Testudinaceae, Wicklowiaceae, Zopfiaceae). Most studies have relied heavily on DNA based sequence analyses based on a limited number of species (i.e. Testudinaceae, Zopfiaceae). This has resulted in inadequate understanding of the genera and species in these families (Jeewon \& Hyde 2007, Zhang et al. 2012). A wider taxon sampling and accurate taxonomic information based on morphological examinations of specimens, coupled with phylogenetic sequence data are needed, to better integrate taxa into appropriate taxonomic ranks in this order.

In this study, we isolated a saprobe from an undetermined, dead, terrestrial substrate in Chiang Rai, Thailand and investigated its phylogenetic relationships as a taxon in Testudinaceae. Placement at the family level is inferred based on analyses of combined DNA sequence data and the taxon is introduced as Muritestudina chiangraiensis gen. et sp. nov. Morphological similarities and differences, coupled with multi-gene phylogeny of the novel taxon are discussed.

\section{Materials and methods}

\section{Isolates and specimens}

Fresh fungal material was collected from Chiang Rai Province in Thailand and brought to the laboratory in a Zip-lock plastic bag. Samples were examined with a Motic SMZ 168 Series microscope. Single ascospore isolation was carried out following the method described in Chomnunti et al. (2014). Germinated spores were individually transferred to Potato Dextrose Agar (PDA) plates and grown at $25{ }^{\circ} \mathrm{C}$ in the daylight. Isolates including accession numbers of gene sequences are listed in Table 1. Isolates listed as MFLUCC are those maintained in the collection of the Culture Collection of Mae Fah Luang University, Chiang Rai, Thailand. Specimens have been deposited in the Mae Fah Luang University (MFLU) fungarium, Chiang Rai, Thailand. Representative isolates and specimens have been deposited in Thailand Bioresource Research Center, Bangkok, Thailand (TBRC) and National Science and Technology Development Agency, Thailand (BBH). Faces of Fungi and Index Fungorum numbers are provided as outlined in Jayasiri et al. (2015) and Index Fungorum (2017), while new species are justified based on recommendations outlined by Jeewon \& Hyde (2016).

\section{Morphological observations}

Hand sections of the ascomata, were mounted in distilled water, and the following characteristics were evaluated: ascomata diameter, height, colour and shape; width of peridium; height and diameter of ostioles. Length and width (at the widest point) of asci and ascospores were measured. Images were captured with a Canon 550D digital camera fitted to a Nikon ECLIPSE 80i compound microscope. Measurements were made with the Tarosoft (R) Image Frame Work program and images used for figures processed with Adobe Photoshop CS3 Extended version 10.0 software (Adobe Systems, USA).

\section{DNA extraction, PCR amplifications and sequencing}

Mycelia for DNA extraction from each isolate were grown on PDA for 3-4 weeks at $25{ }^{\circ} \mathrm{C}$ and total genomic DNA was extracted from approximately $150 \pm 50 \mathrm{mg}$ axenic mycelium scraped from the edges of the growing culture. Mycelium was ground to a fine powder with liquid nitrogen 
and DNA extracted using the Biospin Fungus Genomic DNA Extraction Kit-BSC14S1 (BioFlux, P.R. China) following the instructions of the manufacturer. DNA to be used as template for PCR were stored at $4{ }^{\circ} \mathrm{C}$ for use in regular work and duplicated at $-20{ }^{\circ} \mathrm{C}$ for long-term storage.

DNA sequence data was obtained from the partial sequences of three ribosomal and two protein coding genes. The genes, primers, references and PCR protocols are summarized in Table 2. Polymerase chain reaction (PCR) was carried out in a volume of $25 \mu \mathrm{l}$ which contained $12.5 \mu 1$ of $2 \times$ Power Taq PCR MasterMix (Bioteke Co., China), $1 \mu 1$ of each primer $(10 \mu \mathrm{M}), 1 \mu 1$ genomic DNA and $9.5 \mu$ deionized water. The amplified PCR fragments were sent to a commercial sequencing provider (BGI, Ltd Shenzhen, P.R. China). The nucleotide sequence data acquired were deposited in GenBank (Table 1). The finalized alignment and tree were deposited in TreeBASE, submission ID: 21850 (http://purl.org/phylo/treebase/phylows/study/TB2:S21850).

Table 1 Genes/loci used in the study with PCR primers, references and protocols.

\begin{tabular}{|c|c|c|c|}
\hline $\operatorname{Locus}^{\text {a }}$ & Primers & $\begin{array}{l}\text { PCR: thermal cycles: }{ }^{b} \\
\text { (Annealing temp. in bold) }\end{array}$ & References \\
\hline ITS & $\begin{array}{l}\text { ITS5 } \\
\text { ITS4 }\end{array}$ & $\left(95{ }^{\circ} \mathrm{C}: 30 \mathrm{~s}, \mathbf{5 5}^{\circ} \mathrm{C}: 50 \mathrm{~s}, 72^{\circ} \mathrm{C}: 90 \mathrm{~s}\right) \times 35$ cycles & White et al. (1990) \\
\hline LSU & $\begin{array}{l}\text { LR0R } \\
\text { LR5 }\end{array}$ & $\left(95^{\circ} \mathrm{C}: 30 \mathrm{~s}, \mathbf{5 5}^{\circ} \mathrm{C}: 50 \mathrm{~s}, 72^{\circ} \mathrm{C}: 90 \mathrm{~s}\right) \times 35$ cycles & $\begin{array}{l}\text { Rehner \& Samuels (1994) } \\
\text { Vilgalys \& Hester (1990) }\end{array}$ \\
\hline SSU & $\begin{array}{l}\text { NS1 } \\
\text { NS4 }\end{array}$ & $\left(95^{\circ} \mathrm{C}: 30 \mathrm{~s}, 55^{\circ} \mathrm{C}: 50 \mathrm{~s}, 72^{\circ} \mathrm{C}: 90 \mathrm{~s}\right) \times 35$ cycles & White et al. (1990) \\
\hline$r p b 2$ & $\begin{array}{l}\text { fRPB2-5f } \\
\text { fRPB2-7cR }\end{array}$ & $\left(94{ }^{\circ} \mathrm{C}: 60 \mathrm{~s}, 58{ }^{\circ} \mathrm{C}: 60 \mathrm{~s}, 72^{\circ} \mathrm{C}: 90 \mathrm{~s}\right) \times 40$ cycles & Sung et al. (2007) \\
\hline tefl & $\begin{array}{l}\text { EF1-983F } \\
\text { EF1-2218R }\end{array}$ & $\left(95^{\circ} \mathrm{C}: 30 \mathrm{~s}, 55^{\circ} \mathrm{C}: 50 \mathrm{~s}, 72^{\circ} \mathrm{C}: 90 \mathrm{~s}\right) \times 35$ cycles & $\begin{array}{l}\text { Rehner \& Buckley (2005) Liu } \\
\text { et al. (1999) }\end{array}$ \\
\hline
\end{tabular}

\section{Molecular phylogenetic analyses}

\section{Sequencing and sequence alignment}

Sequences generated from different primers of the three genes were analysed with other sequences retrieved from GenBank (Table 2). Sequences with high similarity indices were determined from a BLAST search to find the closest matches with taxa in Pleosporales, and from recently published data (Hashimoto et al. 2017). The multiple alignments of all consensus sequences, as well as the reference sequences were automatically generated with MAFFT v. 7 (http://mafft.cbrc.jp/alignment/ server/index.html; Kuraku et al. 2013, Katoh et al. 2017), and were improved manually when necessary using BioEdit v. 7.0.5.2 (Hall 1999). Ambiguous regions were excluded from the analyses and gaps were treated as missing data.

\section{Phylogenetic analyses}

Phylogenetic analyses of both individual and combined aligned data were performed under maximum-likelihood, maximum parsimony and Bayesian criteria. Parsimony analysis was carried with the heuristic search option in PAUP (Phylogenetic Analysis Using Parsimony) v. 4.0b10 with the following parameter settings: characters unordered with equal weight, random taxon addition, branch swapping with tree bisection-reconnection (TBR) algorithm, branches collapsing if the maximum branch length was zero. Alignment gaps were treated as missing characters in the analysis of the combined data set, where they occurred in relatively conserved regions. Trees were inferred using the heuristic search option with 1000 random sequence additions, with maxtrees set at 1000. Descriptive tree statistics for parsimony; Tree Length (TL), Consistency Index (CI), Retention Index (RI), Relative Consistency Index (RC) and Homoplasy Index (HI) were calculated 
for trees generated under different optimality criteria. The Kishino-Hasegawa tests (Kishino \& Hasegawa 1989) were performed in order to determine whether trees were significantly different. Maximum parsimony bootstrap values (MP) equal or greater than $60 \%$ are given above each node (Fig. 1). Other details pertaining to analyses (e.g. consideration of TT ratios, comparison of tree topologies, selection of outgroups etc.) are outlined in Jeewon et al. (2004, 2013).

The evolutionary models for Bayesian analysis and maximum-likelihood were selected independently for each locus using MrModeltest v. 2.3 (Nylander 2004) under the Akaike Information Criterion (AIC) implemented in both PAUP v. 4.0b10. GTR+I+G model is resulted in each locus for Bayesian analysis and maximum-likelihood by AIC in MrModeltest as the best-fit model.

Bayesian analysis was conducted with MrBayes v. 3.1.2 (Huelsenbeck \& Ronqvist 2001) to evaluate Bayesian posterior probabilities (BYPP) (Rannala \& Yang 1996; Zhaxybayeva \& Gogarten 2002) by Markov Chain Monte Carlo sampling (BMCMC). GTR+I+G was used in the command. Six simultaneous Markov chains were run for 2,000,000 generations and trees were sampled every 200th generation. The distribution of log-likelihood scores was examined to determine stationary phase for each search and to decide if extra runs were required to achieve convergence, using the program Tracer 1.5 (Rambaut \& Drummond 2007). First $10 \%$ of generated trees were discarded and remaining $90 \%$ of trees were used to calculate posterior probabilities of the majority rule consensus tree. BYPP greater than 0.95 are given above each node (Fig. 1).

Maximum likelihood trees were generated using the RAxML-HPC2 on XSEDE (8.2.8) (Stamatakis et al. 2008, Stamatakis 2014) in the CIPRES Science Gateway platform (Miller et al. 2010) using GTR+I+G model of evolution. Maximum likelihood bootstrap values (ML) equal or greater than $60 \%$ are given above each node (Fig. 1).

Phylograms were visualized with FigTree v1.4.0 program (Rambaut 2012) and reorganized in Microsoft power point (2007) and Adobe Illustrator ${ }^{\circledR}$ CS5 (Version 15.0.0, Adobe ${ }^{\circledR}$, San Jose, CA).

Table 2 Taxa used in the phylogenetic analyses and their corresponding GenBank numbers. The newly generated sequences are indicated in bold.

\begin{tabular}{llllllc}
\hline \multirow{2}{*}{ Species } & \multirow{2}{*}{ Strain no } & \multicolumn{5}{c}{ GenBank Accession no. } \\
\cline { 3 - 7 } & & LSU & SSU & ITS & rpb2 & tef1 \\
\hline Amniculicola immersa & CBS123083 & FJ795498 & GU456295 & - & GU456358 & GU456273 \\
Amniculicola parva & CBS123092 & GU301797 & GU296134 & - & - & GU349065 \\
Angustospora nilensis & MFLU 15-1511 & KT944072 & KT944071 & - & - & - \\
Anteaglonium abbreviatum & ANM925a & GQ221879 & - & - & - & GQ221925 \\
Anteaglonium globosum & ANM925.2 & GQ221911 & - & - & - & GQ221919 \\
Anteaglonium parvulum & MFLUCC 14-0815 & KU922911 & KU922912 & - & - & KU922919 \\
Anteaglonium parvulum & MFLUCC 14-0817 & KU922913 & KU922914 & - & - & - \\
Anteaglonium parvulum & MFLUCC 14-0821 & KU922915 & KU922916 & - & - & KU922921 \\
Anteaglonium parvulum & MFLUCC 14-0823 & KU922917 & KU922918 & - & - & KU922922 \\
Anteaglonium thailandicum & MFLUCC 14-0816 & KU922909 & KU922910 & - & - & KU922920 \\
Aquasubmersa japonica & KT2813 & LC061586 & LC061581 & LC061591 & LC194420 & LC194383 \\
Aquasubmersa japonica & KT2862 & LC061587 & LC061582 & LC061592 & LC194421 & LC194384 \\
Aquasubmersa japonica & KT2863 & LC061588 & LC061583 & LC061593 & LC194422 & LC194385 \\
Aquasubmersa mircensis & MFLUCC 11-0401 & JX276955 & JX276956 & JX276954 & - & - \\
Atrocalyx acutispora & KT2436 & LC194341 & LC194299 & LC194475 & LC194423 & LC194386 \\
Atrocalyx lignicola & CBS122364 & LC194342 & LC194300 & LC194476 & LC194424 & LC194387 \\
Cryptoclypeus oxysporus & KT2772 & LC194345 & LC194303 & LC194479 & LC194427 & LC194390 \\
\hline
\end{tabular}


Table 2 Continued.

\begin{tabular}{|c|c|c|c|c|c|c|}
\hline \multirow{2}{*}{ Species } & \multirow{2}{*}{ Strain no } & \multicolumn{5}{|c|}{ GenBank Accession no. } \\
\hline & & LSU & SSU & ITS & $r p b 2$ & tef1 \\
\hline $\begin{array}{l}\text { Cryptocoryneum } \\
\text { brevicondensatum }\end{array}$ & yone 1 & 4349 & LC194307 & LC096155 & C194431 & LC096137 \\
\hline Cryptocoryneum japonicum & KT3300 & LC194354 & LC194312 & LC096160 & LC194436 & LC096142 \\
\hline $\begin{array}{l}\text { Cryptocoryneum } \\
\text { longicondensatum }\end{array}$ & KT2913 & LC194360 & LC194318 & LC096166 & LC194442 & LC096148 \\
\hline $\begin{array}{l}\text { Cryptocoryneum } \\
\text { paracondensatum }\end{array}$ & KT3241 & LC194362 & LC194320 & LC096168 & LC194444 & LC096150 \\
\hline $\begin{array}{l}\text { Cryptocoryneum } \\
\text { pseudorilstonei }\end{array}$ & CBS113641 & LC194364 & LC194322 & LC096170 & LC194446 & LC096152 \\
\hline Hermatomyces tectonae & MFLUCC 14-1140 & KU764695 & KU712465 & KU144917 & KU712486 & KU872757 \\
\hline Hermatomyces tectonae & MFLUCC 14-1141 & KU764696 & KU712466 & KU144918 & - & KU872758 \\
\hline Hermatomyces tectonae & MFLUCC 14-1142 & KU764697 & KU712467 & KU144919 & KU712487 & - \\
\hline Hermatomyces thailandica & MFLUCC 14-1143 & KU764692 & KU712468 & KU144920 & KU712488 & KU872754 \\
\hline Hermatomyces thailandica & MFLUCC 14-1144 & KU764693 & KU712469 & KU144921 & KU712489 & KU872755 \\
\hline Hermatomyces thailandica & MFLUCC 14-1145 & KU764694 & KU712470 & KU144922 & KU712490 & KU872756 \\
\hline Lepidosphaeria nicotiae & CBS 101341 & DQ678067 & - & - & DQ677963 & DQ677910 \\
\hline Lophiostoma arundinis & CBS 621.86 & DQ782384 & DQ782383 & AJ496633 & DQ782386 & DQ782387 \\
\hline Lophiostoma crenatum & CBS 629.86 & DQ678069 & DQ678017 & - & DQ677965 & DQ677912 \\
\hline Lophiotrema bambusae & RP0030 & KX672154 & KX672159 & KX672149 & KX672161 & KX672162 \\
\hline Lophiotrema eburnoides & KT1424.1 & LC001707 & LC001706 & LC001709 & LC194458 & LC194403 \\
\hline Lophiotrema fallopiae & KT2748 & LC149915 & LC149911 & LC149913 & LC194459 & LC194404 \\
\hline Muritestudina chiangraiensis & MFLUCC 17-2551 & MG602248 & MG602249 & MG602247 & MG602250 & MG602251 \\
\hline Massarina albocarnis & CBS 119345 & LC194379 & LC194337 & LC194503 & LC194471 & LC194416 \\
\hline Neotestudina rosatii & CBS 690.82 & DQ384107 & DQ384081 & & & \\
\hline Polyplosphaeria fusca & KT1616 & AB524604 & AB524463 & AB524789 & - & - \\
\hline $\begin{array}{l}\text { Pseudoastrosphaeriella } \\
\text { bambusae }\end{array}$ & MFLUCC 11-0205 & KT955475 & KT955455 & - & KT955414 & KT955437 \\
\hline $\begin{array}{l}\text { Pseudoastrosphaeriella } \\
\text { longicolla }\end{array}$ & MFLUCC 11-0171 & KT955476 & - & - & KT955420 & KT955438 \\
\hline $\begin{array}{l}\text { Pseudoastrosphaeriella } \\
\text { thailandensis }\end{array}$ & MFLUCC 10-0553 & КT955477 & KT955456 & - & KT955411 & KT955439 \\
\hline $\begin{array}{l}\text { Pseudocryptoclypeus } \\
\text { yakushimensis }\end{array}$ & KT2186 & LC194380 & LC194338 & LC194504 & LC194472 & LC194417 \\
\hline Pseudolophiotrema elymi & KT1450 & LC194381 & LC194339 & LC194505 & LC194473 & LC194418 \\
\hline $\begin{array}{l}\text { Pseudotetraploa } \\
\text { curviappendiculata }\end{array}$ & HC4930 & AB524608 & AB524467 & AB524792 & - & - \\
\hline Quadricrura septentrionalis & HC4983 & AB524799 & - & & & \\
\hline Tetraploa sasicola & KT563 & AB524631 & AB524490 & AB524807 & - & - \\
\hline Trematosphaeria wegeliniana & CBS 123124 & GU261722 & GU261720 & & & \\
\hline Triplosphaeria maxima & KT870 & AB524637 & AB524496 & AB524812 & - & - \\
\hline Ulospora bilgramii & CBS 101364 & DQ678076 & DQ678025 & - & DQ677974 & DQ677921 \\
\hline Verruculina enalia & BCC18402 & GU479803 & GU479771 & - & GU479836 & GU479864 \\
\hline
\end{tabular}




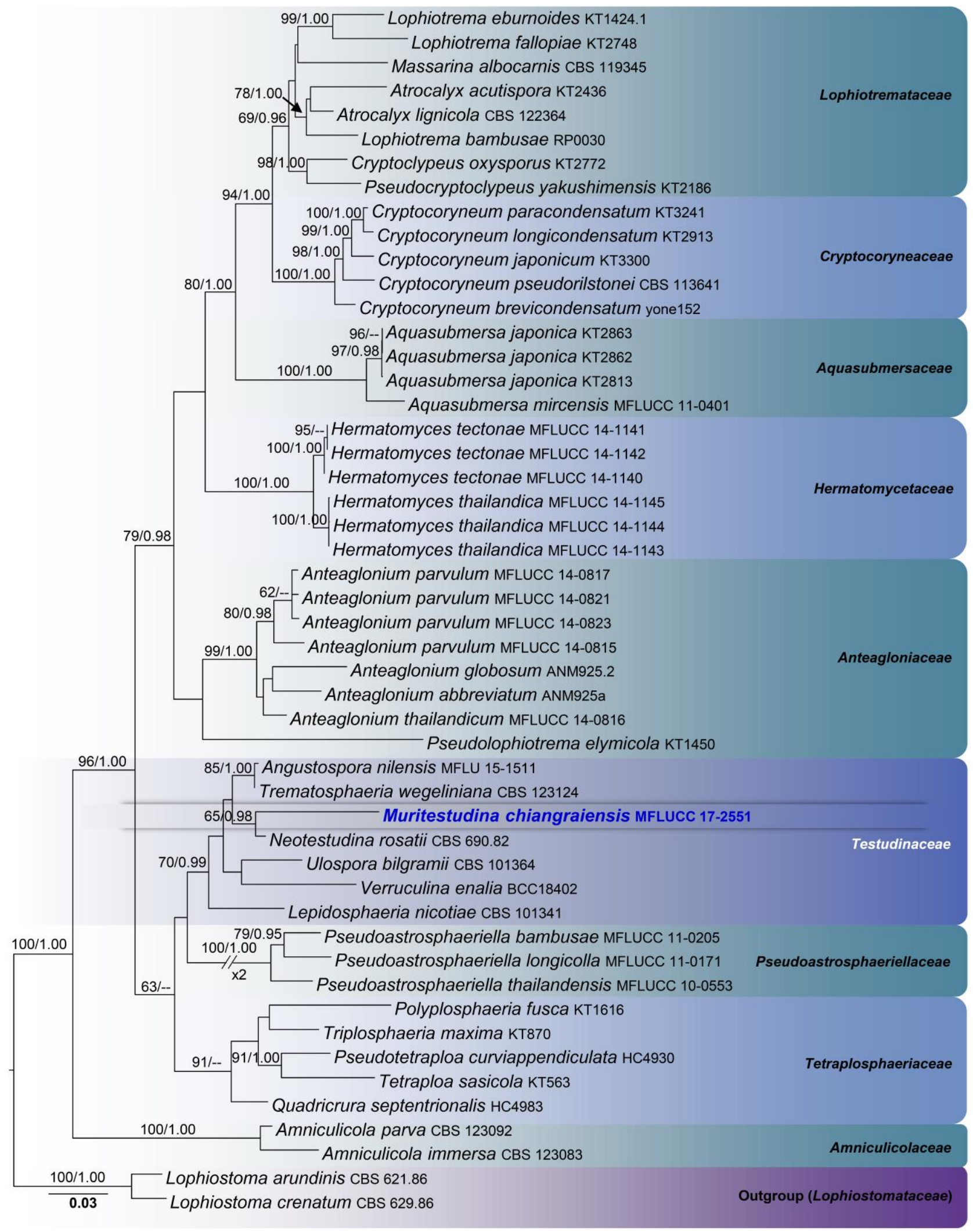

Fig. 1 - RAxML tree based on a combined dataset of partial LSU, SSU, ITS, rpb2 and tef1 DNA sequence analyses. Bootstrap support values for ML equal to or greater than $60 \%$, Bayesian posterior probabilities (PP) equal to or greater than 0.95 are shown as ML/PP above the nodes. The new isolate is in blue. The tree is rooted to Lophiostoma arundinis and L. crenatum (Lophiostomataceae). The scale bar represents the expected number of nucleotide substitutions per site. 


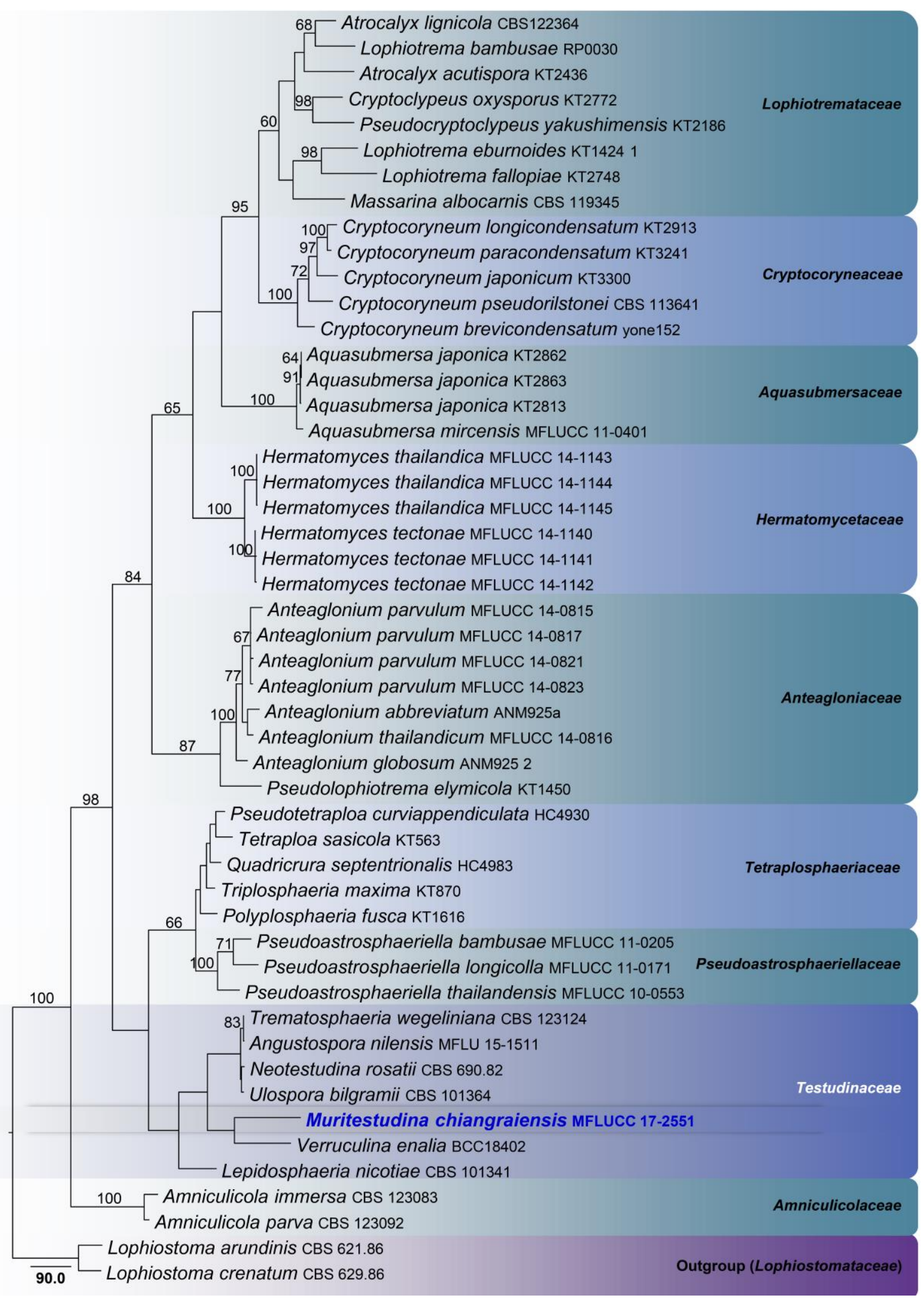

Fig. 2 - The MP phylogram generated from a combined dataset of LSU, SSU, ITS, rpb2 and tef1 DNA sequence analyses. Bootstrap support values for MP equal to or greater than $60 \%$ are shown above the nodes. The new isolate is in blue. The tree is rooted to Lophiostoma arundinis and $L$. crenatum (Lophiostomataceae). The scale bar represents the expected number of nucleotide substitutions per site.

\section{Results}




\section{Phylogenetic analyses}

The concatenated dataset (LSU, SSU, ITS, rpb2 and tefl loci) consisted of 50 strains with 4527 characters representing nine families (Pleosporales) including the new taxon proposed in this study, and Lophiostoma arundinis and L. crenatum as out-group taxa. The RAxML analysis of the combined dataset yielded a best scoring tree (Fig. 1) with a final ML optimization likelihood value of -26038.073582. The matrix had 1420 distinct alignment patterns, with $25.01 \%$ of undetermined characters or gaps. Parameters for the GTR $+\mathrm{I}+\mathrm{G}$ model of the combined LSU, SSU, ITS, rpb2 and tefl were as follows: Estimated base frequencies; $\mathrm{A}=0.248965, \mathrm{C}=0.245265, \mathrm{G}=0.270858$, $\mathrm{T}=0.234913$; substitution rates $\mathrm{AC}=1.334904, \mathrm{AG}=4.505518, \mathrm{AT}=1.221865, \mathrm{CG}=1.221699$, $\mathrm{CT}=9.92271, \mathrm{GT}=1.000$; proportion of invariable sites $\mathrm{I}=0.585813$; gamma distribution shape parameter $\alpha=0.497811$. The Bayesian analysis resulted in 10001 trees after 2000000 generations. The first 1000 trees, representing the burn-in phase of the analyses, were discarded, while the remaining 9001 trees were used for calculating posterior probabilities in the majority rule consensus tree.

The maximum parsimonious dataset (Fig. 2) consisted of 4527 characters, of which 3310 were constant, 932 parsimony-informative (20.6\%) and 285 parsimony-uninformative. The parsimony analysis of the data matrix resulted in 15 equally most parsimonious trees with a length of 4356 steps $(\mathrm{CI}=0.422, \mathrm{RI}=0.645, \mathrm{RC}=0.272, \mathrm{HI}=0.578)$ in the first tree. Tree topologies (generated under ML and Bayesian criteria) from single gene datasets were also compared and the overall tree topology was congruent to those obtained from the combined dataset MP tree (Fig. 2) also recover similar tree topology with respect to the position of the families (except for the Pseudoastrosphaeriellaceae). However, there were major differences in statistical support as compared to the RAxML tree (much lower support observed for a number of clades).

The ML tree generated based on sequence analysis of the combined dataset indicates that our new isolate, Muritestudina chiangraiensis belongs in Testudinaceae and clusters with Neotestudina rosatii (CBS 690.82) with 65\% ML and $0.98 \mathrm{PP}$ statistical support (Fig. 1). Other species viz. Angustospora nilensis (MFLU 15-1511), Lepidosphaeria nicotiae (CBS 101341), Trematosphaeria wegeliniana (CBS 123124), Ulospora bilgramii (CBS 101364) and Verruculina enalia (BCC18402) also group in the Testudinaceae clade with 70\% ML and 0.99 PP statistical support. A notable difference observed herein is the position of our new genus, Muritestudina. In our ML analyses, the latter clusters with Neotestudina rosatii with moderate support, whereas in the MP tree, it clusters with Verruculina enalia in an unsupported subclade.

\section{Taxonomy}

Testudinaceae Arx, Persoonia 6 (3): 366 (1971)

Muritestudina Wanasinghe, E.B.G. Jones \& K.D. Hyde, gen. nov.

Index Fungorum Number: IF554051; Facesoffungi Number: FoF03866

Etymology - The generic epithet is from the combination of two words Muri and Testudina meaning muriform ascospores in Testudinaceae.

Saprobic on unidentified terrestrial dead twigs on the ground. Sexual morph: Ascomata scattered, immersed, coriaceous, black, globose to subglobose, ostiolate. Ostiole central, papillate, with an irregular, pore-like opening, plugged by brown, filamentous hyphae, and occasionally lighter in colour. Peridium composed of 4-5-layers with brown to dark-brown, cells of textura angularis fusing and indistinguishable from the host tissues. Hamathecium comprising septate, cellular pseudoparaphyses, situated between and above the asci, embedded in a gelatinous matrix. Asci 8-spored, bitunicate, fissitunicate, cylindric-clavate, with a distinct pedicel, apically rounded with an ocular chamber. Ascospores overlapping 2-seriate, hyaline, ellipsoidal, 10-12-transversely 
septate, with 2-4-longitudinal septa, muriform, constricted at the septa, guttulate, smooth-walled, surrounded by a thick, wide mucilaginous sheath. Asexual morph: Undetermined.

Type - Muritestudina chiangraiensis Wanasinghe, E.B.G. Jones \& K.D. Hyde

Muritestudina chiangraiensis Wanasinghe, E.B.G. Jones \& K.D. Hyde, sp. nov.

Figs 3,4

Index Fungorum Number: IF554052; Facesoffungi Number: FoF03867

Etymology - Named after the locality from where it was collected, Chiang Rai.

Holotype - MFLU 17-2645

Saprobic on unidentified terrestrial dead twigs on the ground. Sexual morph: Ascomata 250 $350 \mu \mathrm{m}$ high, $300-400 \mu \mathrm{m}$ diam. $(\overline{\mathrm{x}}=331.1 \times 377.2 \mu \mathrm{m}, \mathrm{n}=10)$, scattered, immersed, coriaceous, black, globose to subglobose, ostiolate. Ostiole central, papillate, with an irregular, pore-like opening, plugged by brown, filamentous hyphae, and occasionally lighter. Peridium 20-30 $\mu \mathrm{m}$ wide, composed of 4-5-layers with brown to dark-brown, cells of textura angularis fusing and indistinguishable from the host tissues. Hamathecium comprising 2-3 $\mu \mathrm{m}(\mathrm{n}=30)$, wide septate, cellular pseudoparaphyses, situated between and above the asci, embedded in a gelatinous matrix. Asci $160-180 \times 25-35 \mu \mathrm{m}(\overline{\mathrm{x}}=172.1 \times 30.5 \mu \mathrm{m}, \mathrm{n}=35), 8$-spored, bitunicate, fissitunicate, cylindrical-clavate, with a distinct pedicel (10-30 $\mu \mathrm{m}$ long; $\overline{\mathrm{x}}=21 \mu \mathrm{m}, \mathrm{n}=30)$, apically rounded with an ocular chamber. Ascospores 30-42 $\times 12-15 \mu \mathrm{m}(\overline{\mathrm{x}}=37.3 \times 13.2 \mu \mathrm{m}, \mathrm{n}=50)$, overlapping 2seriate, hyaline, ellipsoidal, 10-12-transversely septate, with 2-4-longitudinal septa, muriform, constricted at the septa, guttulate, smooth-walled, surrounded by a thick, large mucilaginous sheath. Asexual morph: Undetermined.

Culture characteristics - Colonies on PDA: reaching 3-4 cm diam. after 4 weeks at $25^{\circ} \mathrm{C}$, colonies circular, medium dense, flattened, surface slightly rough with edge entire, slightly radiating with concentric rings of mycelium; colony from above, white to creamy, pale brown at the center; from below: honey at the margin, dark brown at the center, producing pale brown pigmentation in agar.

Known distribution - on dead twigs, Thailand.

Material examined - Thailand, Chiang Rai, Mueang Chiang Rai District, Nang Lae, $20.037708 \mathrm{~N}, 99.890775 \mathrm{E}$, on dead twigs of undetermined sp., 25 June 2017, DN Wanasinghe (MFLU 17-2645, holotype (isotype in BBH) - ex-type living culture, MFLUCC 17-2551.

\section{Discussion}

The main objective of this paper is to establish a novel genus based on morphological and molecular data, as well as to fill the gap in our current taxonomic knowledge on the phylogenetic position of the Testudinaceae. Based on analyses of morphological characters within species representing extant Testudinaceae genera, we proposed herein a new genus, Muritestudina, with $M$. chiangraiensis as the type species. Despite some superficial similarities and close relatedness between Muritestudina and Neotestudina rosatii based on our ML analyses, they can be distinguished based on their phenotypes as well as their habitats. Neotestudina is a human pathogen which is characterized by clavate asci with an irregular spore arrangement and broadly truncate, brown, ascospores with a smooth wall (Hawksworth 1979). Muritestudina chiangraiensis is a terrestrial saprobe which has cylindrical-clavate asci and overlapping biseriate, hyaline, smoothwalled, ellipsoidal, muriform ascospores with large guttules in almost every cell (Fig. 3). Comparison of the LSU nucleotides between our new taxon and Neotestudina rosatii (GenBank: DQ384107) used in this analysis reveals 18 (1.8\%) differences that sets our taxon apart. On the other hand, our MP analyses depict an unsupported relationship of Muritestudina with Verruculina enalia. The latter is recorded from marine aquatic habitats (common on mangrove wood) which have cylindrical asci and uniseriate, dark brown, ellipsoidal, ascospores with verrucose to verruculose walls (Hyde et al. 2013, Jones et al. 2015) and hence differs remarkably from our species. A comparison of the 482 ITS $(+5.8 \mathrm{~S})$ nucleotides with Verruculina enalia (GenBank: GQ203796) reveals >50 differences and thus justifies establishment of our new taxon. 
The taxonomy of Testudinaceae has been primarily based on a few unstable morphological characters and DNA sequence data have been analysed for only a relatively small number of species. Von Arx (1971) introduced Testudinaceae to accommodate Testudina, Neotestudina, Lepidosphaeria, Argynna and Pseudophaeotrichum. The presence of ascomata with a dark peridium, bitunicate asci and dark, 2-celled ascospores (about $10 \mu \mathrm{m}$ long) has been considered as significant delimiting characters at the familial level. This classification was followed by Hawksworth (1979) as a result of studies with the scanning electron microscopy (SEM), but Argynna was excluded from Testudinaceae due to its unitunicate asci. Phookamsak et al. (2015) excluded Lojkania from Fenestellaceae and currently Testudinaceae comprises Angustospora, Lepidosphaeria, Lojkania, Neotestudina, Testudina, Ulospora, Verruculina as accepted genera (Wijayawardene et al. 2017).


Fig. 3 - Muritestudina chiangraiensis (MFLU 17-2645, holotype). a, b Appearance of ascomata on host substrate. c Section of ascoma. d Peridium. e Pseudoparaphyses. f-i Asci. j-m Ascospores. $n$ Ascospore stained with Indian Ink. Scale bars: $b=200 \mu \mathrm{m}, \mathrm{c}=100 \mu \mathrm{m}, \mathrm{f}-\mathrm{i}, \mathrm{j}-\mathrm{n}=20 \mu \mathrm{m}, \mathrm{e}=10$ $\mu \mathrm{m}$. 

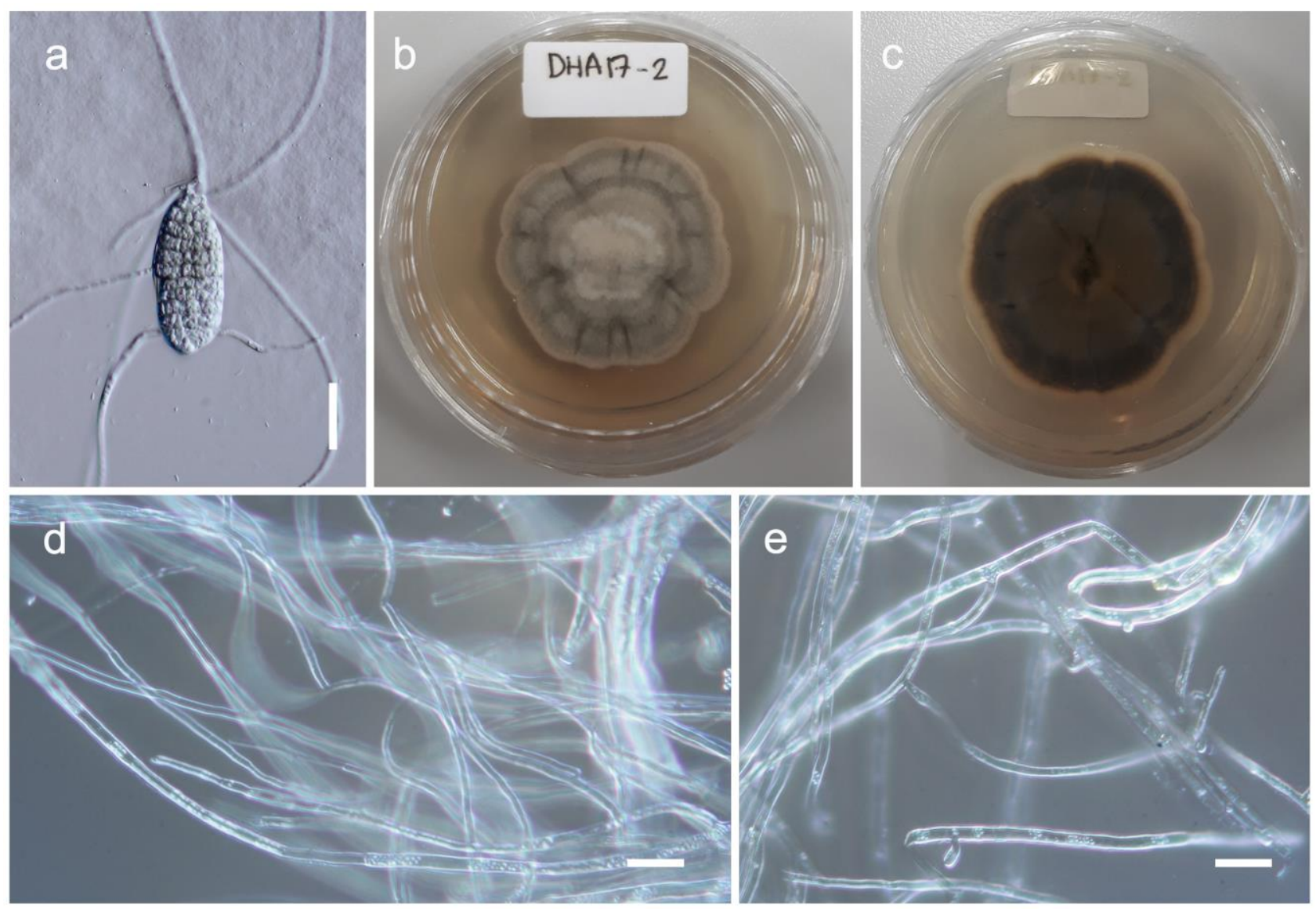

Fig. 4 - Muritestudina chiangraiensis (holotype). a Germinating ascospore. b, c Culture on PDA (note c reverse). $\mathrm{d}$, e Mycelia. Scale bars: $\mathrm{a}=20 \mu \mathrm{m}, \mathrm{d}, \mathrm{e}=10 \mu \mathrm{m}$.

In an attempt to clarify phylogenetic relationships, we also observe that there is a suite of morphological characters that can delineate species of the Testudinaceae from closely related families such as Pseudoastrosphaeriellaceae and Tetraplosphaeriaceae. Species of Testudinaceae are mainly characterized by globose to subglobose ascomata, a peridium comprising cells of textura angularis, clavate to cylindrical asci with short pedicels and ellipsoidal, verrucose to verruculose ascospores with mostly one longitudinal septum. Pseudoastrosphaeriellaceae are characterized mainly by lenticular or hemisphaerical ascomata, a peridium comprising pseudoparenchymatous cells of textura angularis, clavate to cylindric-clavate asci with long pedicels and fusiform to clavate, smooth-walled multi-septate ascospores (Phookamsak et al. 2015). Tetraplosphaeriaceae have hemisphaerical ascomata with a flattened base, a peridium comprising polygonal to hyphoid cells, clavate to cylindrical asci with short pedicels and narrowly fusiform to broadly cylindrical, smooth-walled ascospores with 1-3-septa (Hyde et al. 2013). Our ML phylogenies also provide further taxonomic insights to better define the generic boundaries within the Testudinaceae. Despite sparse taxon sampling and moderate support for the internal subclades, we believe that the genera should be considered as distinct. Some inconsistencies between the estimated ML and MP trees were observed with respect to the placement of several genera within Testudinaceae, but we believe that this may be due to unequal evolutionary rates, different genealogical histories and possibility of insufficient phylogenetic signal of the nuclear and protein genes analysed herein.

From a morphological perspective, the genera of Testudinaceae appear to have different morphologies. A summary of the main morphological characteristics that we consider useful at the intergeneric level are summarized in Table 3. For the time being, it seems appropriate to maintain all of the above-mentioned genera in Testudinaceae. Interestingly this is the first record of hyaline muriform spores in Testudinaceae. Taxa in Halojulellaceae and Shiraiaceae produce hyaline muriform spores similar to our new isolate, but these families are not closely related to 
Table 3 Synopsis of genera in Testudinaceae

\begin{tabular}{|c|c|c|c|c|c|c|c|c|}
\hline Genus & \multirow{2}{*}{ Angustospora } & \multirow{2}{*}{ Lepidosphaeria } & \multirow{2}{*}{ Lojkania } & \multirow{2}{*}{ Neotestudina } & \multirow{2}{*}{ Testudina } & \multirow{2}{*}{ Ulospora } & \multirow{2}{*}{ Verruculina } & \multirow{2}{*}{ Muritestudina } \\
\hline Characteristics & & & & & & & & \\
\hline Habitat & $\begin{array}{l}\text { Aquatic } \\
\text { (freshwater) }\end{array}$ & $\begin{array}{l}\text { Aquatic (muddy } \\
\text { sand) }\end{array}$ & $\begin{array}{l}\text { Terrestrial } \\
\text { (saprotrophic) }\end{array}$ & $\begin{array}{l}\text { Terrestrial } \\
\text { (human } \\
\text { pathogen) }\end{array}$ & $\begin{array}{l}\text { Terrestrial } \\
\text { (saprobic or } \\
\text { parasitic) }\end{array}$ & Terrestrial & $\begin{array}{l}\text { Aquatic } \\
\text { (common on } \\
\text { mangrove wood) }\end{array}$ & $\begin{array}{l}\text { Terrestrial } \\
\text { (saprobic) }\end{array}$ \\
\hline Ascomata shape & $\begin{array}{l}\text { Globose to } \\
\text { subglobose }\end{array}$ & $\begin{array}{l}\text { Globose to } \\
\text { subglobose }\end{array}$ & $\begin{array}{l}\text { Ovoid to } \\
\text { obpyriform }\end{array}$ & $\begin{array}{l}\text { Globose to } \\
\text { subglobose }\end{array}$ & $\begin{array}{l}\text { Globose, } \\
\text { spherical or } \\
\text { tuberous }\end{array}$ & Subglobose & $\begin{array}{l}\text { Ampulliform or } \\
\text { depressed } \\
\text { ellipsoidal }\end{array}$ & $\begin{array}{l}\text { Globose to } \\
\text { subglobose }\end{array}$ \\
\hline Ostiole & Present & Present & Present & Present & Present & Absent & Present & Present \\
\hline Asci shape & Clavate & Clavate & Cylindrical & Clavate & $\begin{array}{l}\text { Clavate or } \\
\text { spherical }\end{array}$ & $\begin{array}{l}\text { Ovoid to } \\
\text { pyriform }\end{array}$ & Cylindrical & $\begin{array}{l}\text { Cylindrical- } \\
\text { clavate }\end{array}$ \\
\hline Spore arrangement & $\begin{array}{l}\text { Overlapping } \\
\text { biseriate }\end{array}$ & & $\begin{array}{l}\text { Overlapping } \\
\text { uniseriate }\end{array}$ & $\begin{array}{l}\text { Irregularly } \\
\text { arranged }\end{array}$ & Uniseriate & $\begin{array}{l}\text { Irregularly } \\
\text { arranged }\end{array}$ & Uniseriate & $\begin{array}{l}\text { Overlapping } \\
\text { biseriate }\end{array}$ \\
\hline Spore color & $\begin{array}{l}\text { Dark-brown to } \\
\text { black }\end{array}$ & Brown & $\begin{array}{l}\text { Pale brown to } \\
\text { dark brown, or } \\
\text { reddish brown, }\end{array}$ & Brown & Brown & Brown & Dark brown & Hyaline \\
\hline Furrows on spores & Lacking furrows & Lacking furrows & Lacking furrows & Lacking furrows & Lacking furrows & $\begin{array}{l}\text { three to six deep } \\
\text { furrows } \\
\text { alternating in } \\
\text { each cell of the } \\
\text { spore }\end{array}$ & Lacking furrows & Lacking furrows \\
\hline Spore surface & Smooth & $\begin{array}{l}\text { Minute } \\
\text { granulate } \\
\text { ornamentation }\end{array}$ & Smooth & Smooth & $\begin{array}{l}\text { Ornamentation a } \\
\text { reticulum }\end{array}$ & Smooth & $\begin{array}{l}\text { Verrucose to } \\
\text { verruculose }\end{array}$ & Smooth \\
\hline Other spore characters & $\begin{array}{l}\text { Biconic, polar } \\
\text { cells are lighter }\end{array}$ & Apiculate & Ellipsoidal & Broadly truncate & $\begin{array}{l}\text { Ellipsoidal, } \\
\text { composed of } \\
\text { rounded cells }\end{array}$ & $\begin{array}{l}\text { Ellipsoidal, } \\
\text { longitudinal } \\
\text { fissures on the } \\
\text { ascospores }\end{array}$ & Ellipsoidal & $\begin{array}{l}\text { Ellipsoidal, } \\
\text { large guttules in } \\
\text { almost each and } \\
\text { every cell }\end{array}$ \\
\hline Septa in spores & 5 & 1 & 1 & 1 & 1 & 1 & 1 & Muriform \\
\hline References & Li et al. 2016 & $\begin{array}{l}\text { Hawksworth } \\
(1979)\end{array}$ & $\begin{array}{l}\text { Phookamsak et } \\
\text { al. (2015) }\end{array}$ & $\begin{array}{l}\text { Hawksworth } \\
\text { (1979) }\end{array}$ & $\begin{array}{l}\text { Hawksworth } \\
\text { (1979) }\end{array}$ & $\begin{array}{l}\text { Hawksworth } \\
\text { (1979) }\end{array}$ & $\begin{array}{l}\text { Hyde et al. } \\
\text { (2013) }\end{array}$ & This study \\
\hline $\begin{array}{l}\text { Number of epithets in } \\
\text { Index Fungorum } \\
\text { (2017) }\end{array}$ & 1 & 2 & 15 & 4 & 1 & 1 & 1 & 1 \\
\hline
\end{tabular}


Testudinaceae in DNA based sequence data analyses (Hyde et al. 2013, Liu et al. 2017). We believe that this character as homoplasious and therefore not phylogenetically significant. In addition, Halojulellaceae members are recorded from marine habitats and Shiraiaceae members only recorded on bamboo, whereas our new isolate was collected from undetermined terrestrial twigs on the ground.

\section{Acknowledgements}

Dhanushka Wanasinghe and Saowaluck Tibpromma would like to thank the Molecular Biology Experimental Center at Kunming Institute of Botany for facilities for molecular work. Saowaluck Tibpromma also thanks the Mushroom Research Foundation (MRF), Chiang Rai, Thailand for the financial support of her study. K.D. Hyde would like to thank the National Research Council of Thailand (Mae Fah Luang University) for grants "Biodiversity, phylogeny and role of fungal endophytes of Pandanaceae" (Grant No.: 592010200112). R. Jeewon thanks University of Mauritius and Mae Fah Luang University for research support. Ishani D. Goonasekara is thanked for her help during collecting trips.

\section{References}

Arx JA. von. 1971 - Testudinaceae, a new family of ascomycetes. Persoonia. 6, 365-369.

Chen Q, Hou LW, Crous PW, Cai L. 2017 - Didymellaceae revisited. Studies in Mycology. 87, 105-159. (DOI 10.1016/j.simyco.2017.06.002).

Chomnunti P, Hongsanan S, Hudson BA, Tian Q, Peršoh D, Dhami MK, Alias AS, Xu J, Liu X, Stadler M, Hyde KD. 2014 - The Sooty Moulds. Fungal Diversity 66, 1-36. (DOI 10.1007/s13225-014-0278-5).

Duong LM, Jeewon R, Lumyong S, Hyde KD. 2006 - DGGE coupled with ribosomal DNA phylogenies reveal uncharacterized fungal phylotypes on living leaves of Magnolia liliifera. Fungal Diversity 23, 121-138.

Hall TA. 1999 - BioEdit: a user-friendly biological sequence alignment editor and analysis program for Windows 95/98/NT. In: Nucleic Acids Symposium Series 41, 95-98.

Hashimoto A, Matsumura M, Hirayama K, Tanaka K. 2017 - Revision of Lophiotremataceae (Pleosporales, Dothideomycetes): Aquasubmersaceae, Cryptocoryneaceae, and Hermatomycetaceae fam. nov. Persoonia 39, 51-73. (DOI 10.3767/persoonia.2017.39.03).

Hawksworth DL. 1979 - Ascospore sculpturing and generic concepts in the Testudinaceae (syn. Zopfiaceae). Canadian Journal of Botany 57, 91-99.

Huelsenbeck JP, Ronquist F. 2001 - MRBAYES: Bayesian inference of phylogenetic trees. Bioinformatics 17, 754-755. (DOI 10.1093/bioinformatics/17.8.754).

Hyde KD, Jones EBG, Liu JK, Ariyawansa H et al. 2013 - Families of Dothideomycetes. Fungal Diversity 63, 1-313. (DOI 10.1007/s13225-013-0263-4).

Hyde KD, Nilsson RH, Alias SA, Ariyawansa HA et al. 2014 - One stop shop: backbones trees for important pytopathogenic genera: I. Fungal Diversity 67, 21-125. (DOI 10.1007/s13225-0140298-1).

Index Fungorum. 2017 - http://www.indexfungorum.org/Names/Names.asp.

Jaklitsch WM, Voglmayr M. 2016 - Hidden diversity in Thyridaria and a new circumscription of the Thyridariaceae. Studies in Mycology 85, 35-64. (DOI 10.1016/j.simyco.2016.09.002).

Jayasiri SC, Hyde KD, Ariyawansa HA, Bhat J et al. 2015 - The Faces of Fungi database: fungal names linked with morphology, phylogeny and human impacts. Fungal Diversity 74, 3-18. (DOI 10.1007/s13225-015-0351-8).

Jeewon R, Hyde K. 2007 - Detection and diversity of fungi from environmental samples: traditional versus molecular approaches. Advanced Techniques in Soil Microbiology 1-15. 
Jeewon R, Hyde KD. 2016 - Establishing species boundaries and new taxa among fungi: recommendations to resolve taxonomic ambiguities. Mycosphere 7, 1669-1677. (DOI 10.5943/mycosphere/7/11/4).

Jeewon R, Ittoo J, Mahadeb D, Jaufeerally-Fakim Y et al. 2013 - DNA based identification and phylogenetic characterisation of endophytic and saprobic Fungi from Antidesma madagascariense, a medicinal plant in mauritius. Journal of Mycology 2013, 1-10.

Jeewon R, Liew E, Hyde K. 2004 - Phylogenetic evaluation of species nomenclature of Pestalotiopsis in relation to host association. Fungal Diversity 17, 39-55.

Jones EBG, Suetrong S, Sakayaroj J, Bahkali A et al. 2015 - Classification of marine Ascomycota, Basidiomycota, Blastocladiomycota and Chytridiomycota. Fungal Diversity 73, 1-72. (DOI 10.1007/s13225-015-0339-4).

Katoh K, Rozewicki J, Yamada KD. 2017 - MAFFT online service: multiple sequence alignment, interactive sequence choice and visualization. Briefings in Bioinformatics, bbx108. (DOI 10.1093/bib/bbx108).

Kirk PM, Cannon PF, Minter DW, Staplers JA. 2008 - Dictionary of the Fungi 10th edn. CABI Bioscience, UK.

Kishino H, Hasegawa M. 1989 - Evaluation of the maximum likelihood estimate of the evolutionary tree topologies from DNA sequence data, and the branching order in hominoidea. Journal of Molecular Evolution 29, 170-179. (DOI 10.1007/BF02100115).

Kodsueb R, McKenzie EHC, Lumyong S, Hyde KD et al. 2007 - Molecular phylogeny of Aquaticheirospora broccolii; a new synnematous hyphomycete taxon from Thailand and its teleomorphic affinities to Massarinaceae. Botanical Journal of the Linnean Society 155, 283296.

Kuraku S, Zmasek CM, Nishimura O, Katoh K. 2013 - aLeaves facilitates on-demand exploration of metazoan gene family trees on MAFFT sequence alignment server with enhanced interactivity. Nucleic Acids Research 41, W22-W28. (DOI 10.1093/nar/gkt389).

Li GJ, Hyde KD, Zhao RN, Hongsanan S et al. 2016 - Fungal diversity notes 253-366: taxonomic and phylogenetic contributions to fungal taxa. Fungal Diversity 78, 1-237. (DOI 10.1007/s13225-016-0366-9).

Li JF, Phookamsak R, Jeewon R, Bhat DJ et al. 2017 - Molecular taxonomy and morphological characterization reveal new species and new host records of Torula species (Torulaceae, Pleosporales). Mycological Progress 16, 447-461. (DOI 10.1007/s11557-017-1292-2).

Liu JK, Hyde KD, Jeewon R, Phillips AJL et al. 2017 - Ranking higher taxa using divergence times-a case study in Dothideomycetes. Fungal Diversity 84, 75-99. (DOI 10.1007/s13225017-0385-1).

Liu YJ, Whelen S, Hall BD. 1999 - Phylogenetic relationships among ascomycetes evidence from an RNA polymerase II subunit. Molecular Biology and Evolution 16, 1799-1808.

Luo ZL, Bhat DJ, Jeewon R, Boonmee S et al. 2017 - Molecular phylogeny and morphological characterization of asexual fungi (Tubeufiaceae) from freshwater habitats in Yunnan, China. Cryptogamie, Mycologie, 38, 1-28. (DOI 10.7872/crym/v38.iss1.2017.27).

Miller MA, Pfeiffer W, Schwartz T. 2010 - Creating the CIPRES Science Gateway for inference of large phylogenetic trees. In: Proceedings of the gateway computing environments workshop (GCE). Institute of Electrical and Electronics Engineers, New Orleans, LA, 14 Nov, pp 1-8.

Nylander JAA. 2004 - MrModeltest 2.0. Program distributed by the author. Evolutionary Biology Centre, Uppsala University.

Ohm RA, Feau N, Henrissat B, Schoch CL et al. 2012 - Diverse life styles and strategies of plant pathogenesis encoded in the genomes of eighteen Dothideomycetes Fungi. PLOS Pathogens 8, e1003037. (DOI 1371/journal.ppat.1003037. Epub 2012 Dec 6).

Phookamsak R, Norphanphoun C, Tanaka K, Dai DQ et al. 2015 - Towards a natural classification of Astrosphaeriella-like species; introducing Astrosphaeriellaceae and 
Pseudoastrosphaeriellaceae fam. nov. and Astrosphaeriellopsis, gen. nov. Fungal Diversity 74, 143-197. (DOI 10.1007/s13225-015-0352-7).

Rambaut A, Drummond AJ. 2007 - Tracer v1, 4. Available from: http://beast.bio.ed.ac.uk/Tracer.

Rambaut A. 2012 - FigTree version 1.4.0. Available at http://tree.bio.ed.ac.uk/software/figtree/

Rannala B, Yang Z. 1996 - Probability distribution of molecular evolutionary trees: a new method of phylogenetic inference. Journal of Molecular Evolution 43, 304-311. (DOI 10.1007/BF02338839)

Rehner S. $2001-$ Primers for Elongation Factor 1- $\alpha$ (EF1- $\alpha)$. http://ocid.NACSE.ORG/research/deephyphae/EF1primer.pdf.

Rehner SA, Buckley E. 2005 - A Beauveria Phylogeny Inferred from Nuclear ITS and EF1- $\alpha$ Sequences: Evidence for Cryptic Diversification and Links to Cordyceps Teleomorphs. Mycologia, 97, 84-98. (DOI 10.3852/mycologia.97.1.84).

Rehner SA, Samuels GJ. 1994 - Taxonomy and phylogeny of Gliocladium analysed from nuclear large subunit ribosomal DNA sequences. Mycological Research 98, 625-634.

Stamatakis A, Hoover P, Rougemont J. 2008 - A rapid bootstrap algorithm for the RAxML web servers. Systematic Biology 57, 758-771. (DOI 10.1080/10635150802429642).

Stamatakis A. 2014 - RAxML version 8: a tool for phylogenetic analysis and post-analysis of large phylogenies. Bioinformatics 30, 1312-1313. (DOI 10.1093/bioinformatics/btu033).

Stergiopoulos I, Kourmpetis YAI, Slot JC, Bakker FT et al. 2012 - In silico characterization and molecular evolutionary analysis of a novel superfamily of fungal effector proteins. Molecular Biology and Evolution 29, 3371-3384. (DOI 10.1093/molbev/mss143).

Sung G-H, Sung J-M, Hywel-Jones NL, Spatafora JW. 2007 - A multi-gene phylogeny of Clavicipitaceae (Ascomycota, Fungi): identification of localized incongruence using a combinational bootstrap approach. Molecular Phylogenetics and Evolution 44, 1204-1223. (DOI 10.1016/j.ympev.2007.03.011).

Torres JMO, Dela Cruz TEE. 2015 - Antibacterial activities of fungal endophytes associated with the Philippine endemic tree, Canarium ovatum. Mycosphere 6, 266-273. (DOI 10.5943/mycosphere/6/3/4).

Vilgalys R, Hester M. 1990 - Rapid genetic identification and mapping of enzymatically amplified ribosomal DNA from several Cryptococcus species. Journal of Bacteriology 172, 4238-4246.

Wanasinghe DN, Hyde KD, Jeewon R, Crous et al. 2017a - Phylogenetic revision of Camarosporium (Pleosporineae, Dothideomycetes) and allied genera. Studies in Mycology, 87, 207-256. (DOI 1016/j.simyco.2017.08.001).

Wanasinghe DN, Phookamsak R, Jeewon R, Wen Jing Li et al. 2017b - Fenestellaceae with descriptions of new Fenestella species and Neocucurbitaria gen. nov. Mycosphere 8, 397414. (DOI 10.5943/mycosphere/8/4/2).

White TJ, Bruns T, Lee J, Taylor SB. 1990 - Amplification and direct sequencing of fungal ribosomal RNA genes for phylogenetics. In: Innis MA, Gelfand DH, Sninsky JJ, White TJ (eds), PCR protocols: a guide to methods and applications: 315-322. Academic Press, San Diego, California, USA.

Wijayawardene NN, Crous PW, Kirk PM, Hawksworth DL et al. 2014 - Naming and outline of Dothideomycetes-2014 including proposals for the protection or suppression of generic names. Fungal Diversity 69, 69: 1-55. (DOI 10.1007/s13225-014-0309-2).

Wijayawardene, NN, Hyde, KD, Rajeshkumar, KC, Hawksworth, DL et al. 2017 - Notes for genera-Ascomycota. Fungal Diversity 86, 1-594. (DOI 10.1007/s13225-017-0386-0).

Woudenberg JHC, Hanse B, van Leeuwen GCM, Groenewald JZ et al. 2017 - Stemphylium revisited. Studies in Mycology 87, 77-103. (DOI 1016/j.simyco.2017.06.001)

Zhang Y, Crous PW, Schoch CL, Hyde KD. 2012 - Pleosporales. Fungal Diversity 53, 1-221. (DOI 10.1007/s13225-011-0117-x). 
Zhang Y, Jeewon R, Fournier J, Hyde KD. 2008 - Multi-gene phylogeny and morpho-taxonomy of Amniculicola lignicola: novel freshwater fungus from France and its relationships to the Pleosporales. Fungal Biology 112, 1186-1194. (DOI 10.1016/j.mycres.2008.04.004).

Zhaxybayeva O, Gogarten JP. 2002 - Bootstrap, Bayesian probability and maximum likelihood mapping: exploring new tools for comparative genome analyses. BMC Genomics 3, 4 (DOI 10.1186/1471-2164-3-4). 